\title{
THE UNITED NATIONS IN THE TIME OF CHOLERA
}

\author{
José Alvarez*
}

Editor's note: The following is the third in our series of posts covering a recent panel discussion ${ }^{1}$ held at the American Society of International Law's headquarters in Washington, DC.

$$
* * * *
$$

The United Nations' handling of the allegations that its peacekeepers in Haiti are responsible for the largest number of cholera cases and deaths in the world is a public relations as well as public health disaster. Even those likely to be skeptical of mono-causal accounts of mass torts or who see that case unsympatheticallyas an incident where "ungrateful" nationals turn on their humanitarian benefactors-cannot possibly be content with how the United Nations has handled this crisis to date. How does one begin to justify a situation in which it takes the United Nations fifteen months to respond to credible allegations of malfeasance ${ }^{2}$, perhaps even recklessness, with a two-sentence response ${ }^{3}$ from its top lawyer that asserts simply, without explanation, that the claims of thousands of victims are just "not receivable" because they implicate "political" or "policy" concerns? How can the United Nations expect anyone to sympathize with its position where, according to the United Nations' own account ${ }^{4}$ of when it is liable for the actions of its peacekeepers, it seems to be saying that the United Nations is responsible only for the small torts of its agents (such as traffic accidents) but not for large ones that cause the deaths of 8,500 and counting?

The United Nations' mishandling of this case is suggested by the unequal terms of trade with respect to the attendant publicity. The plight of some 8,500 victims of cholera concentrated in one of the poorest countries has generated an NGO petition ${ }^{5}$ before the Inter-American Commission on Human Rights; an indepth report ${ }^{6}$ from Yale law and public health students; and expressions of concern and attributed UN blame

* Herbert and Rose Rubin Professor of International Law, NYU School of Law. This essay (and its title) is inspired by Frédéric Mégret's article "La Responsabilite Des Nations Unies Aux Temps Du Cholera (United Nations Responsibility in the Time of Cholera)." After this panel was convened, the U.S. Department of Justice filed a predictable Statement of Interest in the Haiti class action case, affirming the United Nations' absolute immunity, but other class action complaints were filed in U.S. court, see Kristen Boon's blog post on Opinio Juris.

Originally published online 04 April 2014.

1 Remedies for Harm Caused by UN Peacekeepers, ASIL (2014).

${ }^{2}$ Chief of Claims Unit MINUSTAH Log Base, Petition for Relief dated Nov. 3, 2011 from the Chief of Claims Unit MINUSTAH Log Base to the Office of the UN Secretary-General (Nov. 3, 2011).

3 Under Secretary-General for Legal Affairs, Letter dated July 5, 2013 from the U.N. Under Secretary-General for Legal Affairs to Mr. Concannon (July 5, 2013).

${ }^{4}$ UN Secretary-General, Administrative and Budgetary Aspects of the Financing of the U.N. Peacekeeping Operations: Financing of the UN Peacekeeping Operations, UN Doc. A/51/903 (Nov. 4, 1996).

${ }^{5}$ FADISMA; Zanella; Beraldo (2012) Petition to the IACHR concerning the violation, by the UN, of the human right to life and humane treatment, enshrined in articles 4 and 5 of the ACHR and article 1 of the ADRDM (ICHR Protocol n. 1929/11 on 15/03/2012).

6 The Transnational Development Clinic et al., Peacekeeping Without Accountability The United Nations’ ReSPONSIBILITY FOR THE HAITIAN CHOLERA EPIDEMIC 27 (2013). 
by some sixty-five members of the U.S. Congress, ${ }^{7}$ former President Clinton, ${ }^{8}$ and innumerable media outlets including the New York Times. ${ }^{9}$ As this panel demonstrates, it has also generated a high-profile class action lawsuit ${ }^{10}$ in a U.S. district court, along with embarrassingly one-sided panels at highly visible forums such as the American Society of International Law, International Law Weekend, and various law schools. On none of these occasions has the United Nations or any of its officials defended itself against the serious charges alleged. The United Nations has imposed on itself a cone of silence. Not a single UN official has come forward to explain in concrete terms precisely why the claims of the Haitian cholera victims are, despite appearances, not the private law claims that they seem but "public law" claims from which the United Nations is immune - as if the United Nations were immune from the court of public opinion and not only in national courts. An organization that has committed itself at the highest levels to the promotion and fulfillment of the rule of law apparently sees no contradiction in promoting accountability-including legal accountability - in others while refusing to address how the national or international law applies to itself in this case.

The United Nations' only response to date, the letter from its legal counsel, implicitly relies on immunity from suit—as if that were a satisfactory response to allegations that not only did the United Nations fail to screen peacekeepers for a disease common to their place of residence, but that it also failed to supervise the disposal of black water from those peacekeepers in violation of basic standards of care propounded by numerous codes for humanitarian assistance including the Sphere standards; ${ }^{11}$ UNICEF's Handbook on Water Quality; ${ }^{12}$ the UNHCR's Handbook for Emergencies; ${ }^{13}$ the WHO's Technical Notes on DrinkingWater, Sanitation, and Hygiene in Emergencies; ${ }^{14}$ or the Field Manual on Excreta Disposal in Emergencies ${ }^{15}$ of the Water, Engineering, and Development centre at Loughborough University. Worse still, the United Nations waited until January 6, 2011 — several months after the first cholera case in Haiti-to announce that it would form a panel of experts to investigate the source of cholera, thereby exacerbating the continuing harm and making any possible remedy all the more difficult. The result is that Haiti today continues to have a higher than advisable rate of cholera infection (1 percent) - in a country that had no known cases prior to the arrival of the United Nations peacekeepers in 2010-which means that it is only one tropical storm/hurricane away from a renewed public health calamity.

This ever-present threat of a cholera epidemic has finally spurred the United Nations into action. Today, the United Nations is engaged in negotiations with the Haiti government to give effect to an ambitious $\$ 2.3$ billion plan ${ }^{16}$ to build the infrastructure needed to protect Haiti's water supply from further risks of infection. At the same time, the United Nations has apparently imposed a pre-condition on those talks and any subsequent action. It has apparently insisted, with some resistance from some within the Haitian government, that

\footnotetext{
${ }^{7}$ Members of U.S. Congress, Letter dated Jan. 10, 2014 from Members of U.S. Congress to the U.S. Permanent Representative to the U.N. (Jan. 10, 2014).

${ }^{8}$ Matthew Mosk, Bill Clinton, UN Envoy, Admits Peacekeepers as Source of Haiti Cholera, ABC NEws (Mar. 9, 2012).

${ }_{9}^{9}$ N.Y. Times Editorial Board, Haiti's Imported Disaster, N.Y. Times (Oct. 12, 2013).

${ }^{10}$ Class Action Complaint \& Demand for Jury Trial, Georges v. United Nations, No. 13-CV-7146 (S.D.N.Y. Oct. 9, 2013).

11 The Sphere Project, Humanitarian Charter and Minimum Standards in Humanitarian Response (2011).

12 United Nations ChildRen's Fund, UNICEF HANDBOOK ON WATER QUALiTy (2008)

13 United Nations High Commissioner for Refugees, HANDBOOK For EMERGENCIES (4th ed. 2015).

14 World Health Organization, Technical Notes on Drinking-Water, Sanitation and Hygiene in Emergencies: PLANNING FOR EXCRETA DISPOSAL IN EMERGENCIES (2011).

15 Peter Harvey, Excreta Disposal in Emergencies, A Field Manuel (2007).

16 PAHO/WHO Calls for International Funding of New Haiti Cholera Plan, REGIONAL OfFiCE FOR THE AMERICAS, WORLD HEALTH ORGANIZATION (Feb. 28, 2013).
} 
those negotiations not include discussions of the tort claims of victims or the United Nations' liability for those. This means that at this writing, even after its own panel of experts determined that in all likelihood the United Nations' peacekeepers were responsible for the introduction of cholera to Haiti, the organization expects not to address those basic accountability issues - as if the families of the dead and those who continue to suffer the physical or mental ravages of the disease should accept that their suffering was an act of God, and not an act of the United Nations. As I suggest below, one of the possible lessons of the Haiti case is precisely a disconnect between how UN officials have historically seen themselves - as a kind of secular God for the international community - and the more pedestrian way that organization is now seen by outsiders, namely as just another governance institution whose legitimacy rests on its accountability. But before we address the broader lessons, let's consider how an organization better attuned to modern sensibilities in favor of the rule of law might have responded.

The United Nations' Possible Legal Responses

\section{Immunity}

The United Nations' legal responses would vary depending on the venue. Its response to the suit in U.S. court is obviously that it is absolutely immune from suit absent its express waiver under article 2 of the General Convention of the Privileges and Immunities of the UN. ${ }^{17}$ Yet, there is every reason to assume, based on prior instances before U.S. courts, that even this defense will not need to be made by the United Nations-but will be made by the U.S. Department of State on its behalf. The claim of immunity has every likelihood of success. There is no known instance where a national court in the U.S. or elsewhere has declined to recognize the United Nations' comprehensive immunity. Indeed, the same circuit that is now hearing the class action has affirmed that even tort claims cast as violations of the International Covenant on Civil and Political Rights are unsuccessful since these arise under a non-self-executing treaty whereas the General Convention is self-executing, while also affirming the United Nations' absolute immunity even in the face of a complaint alleging a violation of the U.S. constitution. ${ }^{18}$

A judge inclined to revisit the application of immunity despite the prior caselaw may want answers to some questions. Is the absolute immunity granted by article 2 of the General Convention a quid pro quo contingent on the organization's compliance with that same treaty's article 29, which requires the United Nations to make available "appropriate modes of settlement" for private law claims? Should a judge "balance" these two provisions and recognize only that immunity that is indeed "necessary" to fulfill the organization's purposes (as is suggested by the text of article 105 of the UN Charter) ${ }^{19}$ which arguably prevails given the higher status of the Charter over other treaties? Should a judge consider that the object and purpose of the General Convention on Privileges and Immunities is to prevent interference by member governments through their courts and that this threat to the independence of the organization is considerably lessened when those courts are only adjudicating garden-variety tort suits by private individuals deploying concepts of negligence common to the world's legal systems? Should a judge consider, when balancing the United Nations' "contingent" right to immunity, whether the particular suit poses genuine threats to the internal functioning of the organizationor put the evidentiary burden on the United Nations to articulate precisely what those threats are?

${ }^{17}$ Convention on the Privileges and Immunities of the United Nations, Feb. 13, 1946, 1 UNTS 15.

18 See Do Rosario Veiga v. World Meteorological Organisation, No. 08-CV-3999, (S.D.N.Y Mar. 3, 2009).

${ }^{19}$ UN Charter art. 105. 
Other courts, most notably in Italy and Belgium, have sometimes been amenable to such inquiries and in a few instances (but not involving the United Nations) have refused to recognize immunity ${ }^{20}$ where the organization has failed to provide an effective remedy or has failed to provide a sufficient independent or impartial one. In many of those instances, the courts have perceived a conflict between the organizational immunity conferred by a treaty and the effective remedies guaranteed to individuals under the European Convention on Human Rights and in some cases have struck the balance in favor of the latter. There is also another potential treaty conflict in the Haiti case: namely between the provisions of the SOFA between Haiti and the United Nations (where the latter accepts liability for violations of Haiti law and agrees to establish a claims settlement commission to solve unresolved claims) and the General Convention's conferral of absolute immunity. Even if the SOFA cannot be read as a waiver of the United Nations' immunity, should its absolute immunity give way where the United Nations has "materially breached" the SOFA by failing to accept its liability for private claims that would otherwise be fully within the jurisdiction of Haitian courts?

\section{Contesting Causation}

The United Nations could try to contest the facts. It could rest its defense on the following conclusion rendered by the Final Report ${ }^{21}$ of its own Panel of Independent Experts:

The introduction of this cholera strain as a result of environmental contamination with feces could not have been the source of such an outbreak without simultaneous water and sanitation and health care system deficiencies. These deficiencies couples with conducive environmental and epidemiological conditions allowed the spread of the vibrio cholera organize in the environment, from which a large number of people became infected. The Independent Panel concludes that the Haiti cholera outbreak was caused by the confluence of circumstances as described above and was not the fault of, or deliberate action of, a group or individual. (at p. 29; emphasis in original)

To be sure, this is not a normatively attractive defense; it essentially blames the very conditions that prompted repeated UN interventions, all known to the United Nations, for the epidemic. It is also not a particularly convincing defense given the conclusions reached by the Yale report ${ }^{22}$ mentioned earlier, as well as the clarifications ${ }^{23}$ issued by experts of the UN Independent Panel.

Rather than denying that its peacekeepers were the 'but for' cause of the epidemic, the United Nations could try to say that it did nothing wrong. Its strongest defense along these lines would be to contest the claim, prominent on the face of the class action complaint, that the failure to screen the Nepalese peacekeepers prior to deployment or the failure to give them prophylactic vaccines prior to their arrival in Haiti constituted negligence. The United Nations could point out that these omissions are consistent with the relevant duty of care as established by the WHO. As far as the allegations that the Nepalese peacekeepers' base camp violated applicable standards for the treatment or removal of black water, presumably the United Nations would claim that violations of the United Nations' own hygienic guidelines should be attributed to Nepalese peacekeepers themselves (and therefore to Nepal) and not to any negligence on its part. Of course passing the buck to financially strapped Nepal would hardly lead to compensation for anyone.

20 August Reinisch, The Immunity of International Organizations and the Jurisdiction of their Administrative Tribunals, 7 CHINESE J. INT'L L. 285 (2008).

21 Independent Panel of Experts on the Cholera Outbreak in Haiti, Final Report of the Independent Panel of EXPERTS ON THE CHOLERA OUTBREAK IN HAITI (2010).

22 See The Transnational Development Clinic et al., supra note 6.

${ }^{23}$ Colum Lynch, Cholera Outbreak, in Haiti in 2010 Tied to U.N. Peacekeepers, Report Says, WASH. POST (July 25, 2013). 
While the United Nations could try to explain why the Haiti victims' claims are "public" and not private claims, Frédéric Mégret has thoroughly addressed ${ }^{24}$ why such a defense seems untenable. As he points out, it is hard to see how these claims - which sound in tort and are conceptually no different than garden variety claims for traffic accidents that the United Nations has routinely accepted - can be seen as "public." Nor, as he and others have pointed out, is it plausible to see how the United Nations could argue that what is being contested here is the scope or mandate of its peacekeeping mission in Haiti. A UN defense based on the exception for "operational necessity" seems untenable for much of the same reasons. And if what the O'Brien letter means to say is that the consideration of the claims of the Haiti cholera victims would be likely to raise questions about the wisdom of some UN policies - as with respect to whether peacekeepers should be screened or treated prior to arrival or what supervision should be exercised when they build their latrines-those questions surely cannot transform a private tort claim into something else. Virtually all tort claims - including claims for negligent driving — raise questions about the day to day policies of the entity being sued. Tort law is not just about compensating injured parties; it is about changing the behavior and operational policies that encourage or fail to prevent negligence. A response that tort complaints are "policy" claims because the policies of the tortfeasor may be questioned is a defense that only someone who has never had to face a tort suit could possibly make.

\section{Other Public Policy Contentions}

The United Nations could make a number of other policy arguments to resist tortious liability. They could argue that the NGO petition and U.S. class action suit crowd out consideration of broader remediesparticularly the United Nations' announced plan to provide Haiti with a permanent solution to its water supply problem. The United Nations could argue that the prospect of monetary compensation for each one of the Haiti victims, including the families of the 8,500 who have died and the thousands more who were made ill, possibly to the maximum cap allowed by UN resolutions (namely $\$ 50,000$ per individual) is not only politically unrealistic, it is profoundly unwise since it is likely to create tensions among the very people most affected while soaking up all the attention that should be devoted to permanently preventing another outbreak. It would also crowd out discussion of solutions for the four other countries to which cholera has spread in the hemisphere.

The United Nations could also argue that the current limitations on its liability - the self-imposed cap on damages, the limitation to private claims, and the assumption that any Standing Claims Commission under the SOFA would be established at the behest of the Haitian government-all reflect concerns that the actions and inactions of peacekeepers invoke the shared responsibility of the United Nations and the host state and should be the province of both to resolve without interference. It could argue that leaving such issues for governments and the United Nations to negotiate is more likely to address the broader public health concerns-without tort lawyers and their own motivations getting in the way.

These policy arguments are consistent with contentions that the most effective tools for international organization (IO) accountability are forms of political accountability and not legal responsibility—namely inspection panels, ombudspersons, or other tools to deter negligence (such as enhanced supervision of officials or encouraging greater control over peacekeepers by troop-contributing nations).

${ }^{24}$ Frederic Megret, La Reponsabilite Des Nations Unies Aux Temps Du Cholera (United Nations Responsibility in the Time of Cholera) (2013). 
Underlying all of these contentions is presumably the United Nations' concern for establishing an adverse precedent. If the Haiti victims are compensated, what other claims against peacekeepers will emerge? Aren't tort suits like this one effectively a zero sum game that not only distract the organization from its core mission but also encourage states to intervene more forcefully in day-to-day UN decisions at headquarters, discourage them from participating in UN peacekeeping, or discourage peacekeeping financial contributions?

While all of the responses noted above are contestable, it would have been better had the United Nations made them earlier. Its current posture-silence-is not an effective alternative.

Other UN defenses to the Haiti case are politically unlikely, though legally plausible. This includes a defense that the United Nations is simply not subject to the primary obligations asserted, even if these are cast in human rights terms - that is, as violations of the right to life, to health, or the right to an effective remedy. While academics and others have debated whether human rights are indeed applicable to the UN—and if so which rights and how-the United Nations is not likely to contest the point and its past practice with respect to at least some of these rights would make the claim appear hypocritical.

\section{The Broader Ripples of the Haiti Case}

As the academic on this panel, I was urged to consider the broader implications. Here are five:

\section{Culture Clash}

The United Nations' time of cholera straddles two distinct cultures. On the one hand, there is the culture of the General Convention's absolute immunity: where the venerable organization, the hope of the international community, is accorded privileges exceeding those accorded to states because of the greater good that it does; where no primary or secondary rules of legal responsibility clearly apply to it unless it has, through its own practice, acquiesced in them; where the United Nations alone decides when and where it will be accountable and to whom; and where its actions and omissions receive the benefit of the doubt, and remain untransparent unless the organization itself lifts the veil. This is a culture built on the premises of diplomatic espousal, where international legal persons get to decide whether and when to compensate private parties.

The Haiti case reveals another culture: a world where the limited remedies of diplomatic inter-state espousal increasingly give way to direct suit by non-state parties suing on their behalf, whether in national court, regional human rights courts, or through ad hoc or investor-state arbitrations. In this alternative human rights universe, states and IOs are increasingly expected to provide effective remedies to those whom they harm. In this alternative universe, those who govern, whether at the national or international level, are seen as both agents of and subjects of the rule of law. This is the culture that produces the ILC's "articles of IO responsibility" and encourages restive non-state actors, including NGOs and lawyer-activists willing to resort to American-style aggressive litigation tactics (including resorts to media savvy mobilizations of shame) to make real the promise of legal accountability suggested by those articles. In this alternative culture, the public/private divide has dissolved or blurred to the point that few believe that merely seeking a remedy against a public actor renders a dispute non-justiciable. It is this culture that the United Nations invokes in its manifold efforts on behalf of the "rule of law." 25 The United Nations is now caught in between these two cultures, both of its making. Like a doe in the headlights, it seems unable to move.

${ }^{25}$ United Nations and the Rule of Law, UNITED NATIONS. 


\section{The Limits of the ILC's Articles of IO Responsibility}

For those who thought that the ILC's recent articles of IO responsibility solve the accountability problem, the Haiti case suggests those articles' trifecta of irrelevance. The ILC's efforts do not contribute much to resolving the concrete challenges posed by the Haiti petitioners for at least three reasons. First, those articles are mostly about the responsibility of IOs to each other and to states; except to the extent that they anticipate piercing the IO veil to reach member states, they say little about the direct responsibility that IOs may owe to individuals. Second, those general rules tell us little in instances where a particular legal regime of organizational responsibility exists—as in the case of UN peacekeeping; the articles of IO responsibility do not clarify how the lex specialis rules governing peacekeepers (including under the SOFA) ought to be interpreted. Third, the ILC said nothing about the "primary" rules to which IOs are subject-nothing about whether the United Nations needs to accord "effective remedies" or respect either Haitian private law or human rights.

\section{Global Administrative Law matters}

As suggested by the United Nations' "public policy" defenses above, the time of cholera is an opportunity to address with more rigor what it means to make IOs "accountable." The public health dimensions of cholera, including its spread beyond Haiti, may tell us that remedies need to go beyond tort suits for an enumerated class of victims. Fundamental questions about what tort law is for are raised in a context where both ex ante regulation and reliable ex post enforcement are scarce-unlike the typical tort suit against domestic tortfeasors. What is the best approach to deterring negligent actors and compensating victims in cases where irreparable harm has been done to thousands and no clear route exists to finding the money for direct compensation? Solving the cholera threat while also making IOs more accountable seems to require consideration of the full range of ex ante and ex post options that well-ordered states apply to make the administrative state accountable. It may mean reconsideration of caps on damages and existing insurance schemes, as well as consideration of opportunities to correct standing UN policies through notice and comment, ombudspersons, or inspection panels. It may mean lump sum global settlements as between the United Nations and the Congo in 1965 but involving the participation of civil society and victims (and not only the Haitian government and the United Nations).

\section{"Human Rights" or "Torts"?}

Although U.S. scholars, accustomed to seeing human rights claims through the parochial lens of the Alien Tort Act, tend to equate the two, human rights claims are not identical to tort claims. Torts are based on violating a standard of care; human rights claims are based on breaches of the bond between a subject and government. The latter have a more ample application insofar as states are required to protect, respect, and ensure or fulfill them.

The cholera case tests these distinctions. At what point does a UN peacekeeping mission which seizes the reins of governance in a fragile state whose own government owes its existence to the UN, become responsible de facto for ensuring human rights and not merely for breaches of a standard of care? At what point does it become irrelevant whether that governance institution was negligent? Should the fragility of the Haitian government, including its inability to talk back to its UN benefactor, be relevant to how one reads the SOFA's anticipated remedies or the scope of UN immunity? At what point does organizational immunity, conferred for other purposes and in other contexts, become inapposite where the United Nations is, de facto, the government? More generally, is absolute immunity tenable or legitimate in the age of rights? 
On the other hand, if the Haitian claims are human rights claims that one could make against one's government, doesn't this demonstrate their "public-ness"? The Haiti claims and the United Nations' response that these are not "receivable" force us to reexamine these questions.

\section{Infectious Diseases and Public Health}

The United Nations' Independent Expert report ${ }^{26}$ ended with two recommendations:

The international community should investigate the potential for using vaccines reactively after the onset of an outbreak to reduce cholera caseload and spread of the disease . . . [T] he United Nations should promote the use of molecular microbial techniques to improve surveillance, detection, and tracking of the Vibrio cholera, as well as other disease-causing organisms that have the potential to spread internationally. (p.5)

As this suggests, the Haiti case may prompt reconsideration of established WHO policies both with respect to inadvisability of the screening international travelers for infectious diseases as well as the potential for preventive vaccines for those already infected. Should these policies be revisited at least in the context of travelers from cholera infested regions to places like Haiti whose populations were particularly vulnerable to the disease given the water supply conditions in place and their pre-existing lack of immunity? More generally, the United Nations' recommendations remind us that this crisis involves two of the poorest countries in the world, Haiti and Nepal, and a disease that is associated with the poorest of the poor. The last two recommendations imply that this disease may not have received the attention devoted to diseases of the developed world. If so, the Haiti case exposes a sadly all too familiar North/South gap in the tools for global governance.

26 See Independent Panel of Experts on the Cholera Outbreak in Haiti, supra note 21. 